
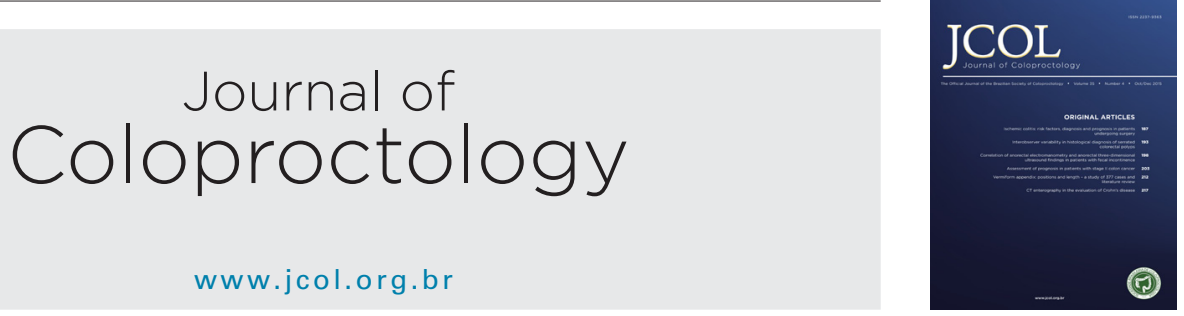

\title{
Editorial
}

\section{T'chorim, Emerods, Hemorrhoids: From the Hebrew Scriptures to today}

\section{T'Chorim, Emerods, Hemorróidas: das Escrituras Hebraicas até hoje}

Hemorrhoidal disease remains one of the commonest afflictions seen by surgeons and gastroenterologists worldwide. Knowledge of its existence as well as its treatments dates from time immemorial. Several studies have already been published about its history, epidemiology, and treatment modalities, yet no consensus has been reached about its precise incidence, prevalence, and standard of care to date. ${ }^{1}$ Epidemiologic data is plagued by methodological bias including patients' information, since they are often embarrassed by their condition to report to their own doctors, or to look for medical attention in the first place. A Brazilian adage says: "those who have money and hemorrhoids don't tell" and, as far as treatment is concerned, the majority of patients panic just by hearing the word 'surgery'.

The leitmotif of therapy is symptom control and prevention of recurrence. Those endpoints are difficult to reach in the real world, however, since hemorrhoids (English synonym: piles) do often present themselves in different stages and combinations, or coexistence with other anorectal ailments such as skin tags, residual plicomas, anal fissures, etc. Hemorrhoids may be internal or external, or both, single or multiple, and have different sizes, in the same patient. Therefore, a defini-

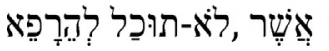

tive conclusion about the ideal therapy for hemorrhoids is close to utopian.

Surgical treatment, mostly by pile excision, have been generally regarded as the most effective way to eradicate symptoms and to avoid recurrence, and may be older than the existence of Hippocrates himself. ${ }^{2}$ He described in detail some forms of hemorrhoid treatments, including cauterization (..."force out the anus as much as possible with the fingers, and make the irons red-hot, and burn the pile until it be dried up, and so as that no part may be left behind..."), and excision ("... Having got the anus to protrude as much as possible, foment with hot water, and then cut off the extremities of the hemorrhoids. .."). ${ }^{3}$ No wonder hemorrhoid-stricken patients have been fleeing from their doctors for more than 2000 years...

The notion of hemorrhoids as a human affliction has been mentioned or documented in many cultures and civilizations throughout history. So was their treatment. Ancient texts and their translations often don't leave us a clear notion as to whether the referred anal symptoms, or suffering, did indeed derive from actual hemorrhoids (as we now know them), or from any other anal disease. Some authors cite Egyptian writings, some authors cite the Old Testament itself. As to the latter, the original Hebrew text of the Torah specifically states (verbatim) the same Hebrew word currently used for "hemorrhoids": techorim or, t'chorim (טְחוֹרים). It is the same uniterm used for hemorrhoids in current Israeli medicine and Hebrew medical literature today. ${ }^{1}$

Rabbi Daniel Eskinazi, from Beit Chabad, São Paulo, Brazil, explains that in the original Hebrew text of Deut 28:27 (Dvarim, 28:27 ?ִּרִרים) hemorroids are referred to and read out loud during prayers as techorim, or t'chorim, a more polite term then apolim which precedes techorim in the text:

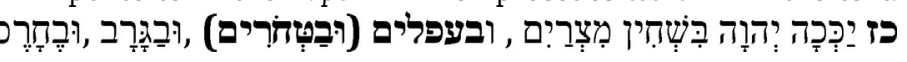
(vapolim and u-vatechorim are in bold). Techorim or techorei are also found in 1 Samuel 5:6, and 1 Samuel 6:4, 1 Samuel 6:11. Techorim was translated as "emerods" in King James Bible, and was thus cited as biblical quotation in some hemorrhoid papers. ${ }^{5}$ This English bible version, whose project started in 1604 A.D., reportedly translated the Old Testament directly from Hebrew and Aramaic, and from the New testament in Greek. ${ }^{6}$ Yet, emerods has no Hebrew or Aramaic roots and

\footnotetext{
${ }^{1}$ Professor Samuel Argov, Haifa, Israel.
} 
does not appear in any original text of the Torah, Mishnah, Gemara, or the Talmud, so it is a misnomer. It is most certainly an English adaptation of the Greek word equivalent for hemorrhoids (aimorro $\left.{ }^{\circ} d e s, \alpha \iota \mu \rho \rho 0{ }^{\circ} \delta \varepsilon \zeta\right)$ which is used by virtually the whole scientific world. Some authors, as Dr. Goligher in his famous textbook, often cite "hemorrhoids" as deriving from haima (blood) and rhoos (which they translated as "flow" or "flowing"). ${ }^{7}$ Haima is correct ( $\alpha \iota \mu \alpha$, aíma, aímatos, and other variants), yet the correct Greek words for "flow" or "to flow" would be $\rho \mathrm{O} \eta, \rho \mathrm{O} \iota, \rho \mathrm{O} \varepsilon$ (roh, roí, roé) and $\rho \mathrm{O} v v$ (réoun) for "flowing". The Greek sufix $\varepsilon \delta \mathrm{O} \zeta$, eidos, or oides ("similar to, type", "resembling", "shape of") explains the formation of the final word which was consacrated along time (haimaroí-ides). It atests the bleeding nature of the disease which caught the attention of ancient physicians. The Latin version of the word, most certainly Greek-derived, is homorrhŏida (plural høemorrhoidae) from which the vast majority of Latinderived languages refer to, probably once the Septuaginta was later used by Eusebius Hieronymus, to write the Vulgata, a Latin version completed around $405 \mathrm{AD} .^{8}$

At any rate it points out to what the Bible actually referred to originally, since any Greek version likely interpreted it as a round-shaped, tumor-like, or a bubo, either internally or externally to the anal canal. A common citation of a King James Bible passage in hemorrhoid papers is from Deut 28:27: "The LORD will smite thee with the boils of Egypt, and with the emerods, and with the scab, and with the itch, whereof thou canst not be healed." Yet, other English translations of this verse refer to the "emerods" portion as "tumors". 6 It wouldn't surprise us if hemorrhoids may have been visualized in the past as thrombosis and its related suffering, or if they were observed as prolapse. So, any round-shaped tumor-like appendage or protrusion from the anus could well have been a hemorrhoid, to be later referred to in English as pile (derived from the Latin word pila, for ball). ${ }^{9}$ Of course another possibility is whether those "tumors" were of infectious nature including, potentially, condylomata or syphilis, since they are mentioned in the Bible to induce suffering as a "punishment from God". Again, one of the often cited passages of the Torah relating to hemorrhoids could at least be amenable to that possibility (From King James Bible, 1 Samuel 6:4: “. . .'Five golden emerods, and five golden mice, ... for one plague was on you all, and on your lords.") (From the Torah: Torah

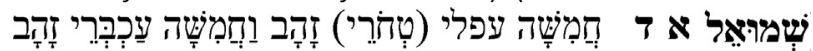

"Emerods" and "t'chorei" may go along with mice as plagues as chastisements in this passage. There were indeed rat or mouse related infections at the time (maybe buboes thus related to a bubonic plague), or at least rodent invasions from time to time, which certainly was not regarded as anything good. ${ }^{10}$ Interestingly, past theories for hemorrhoid formation also proposed they could derive from inflammation or infection, and, even more interestingly, this hypothesis has actually been currently resumed. Morgado et al. showed from 100 surgical specimens that hemorrhoids presented intense inflammation affecting blood vessels and its collagen support. ${ }^{11}$

The Master Surgeon John of Ardene in his famous "Treatises of Fistula in Ano, Hemorrhoids, and Clysters" (1370 AD) already pointed out the difference between piles or "emeroydez", as he called them (derived from the Greek), which contained blood and bled, and condilomata (round shaped tumors or, as he wrote, "the shape of a fist y-closed") which did not bleed. ${ }^{12}$ It is thus likely that the writers of King James' Bible knew about Ardene's and other author's mentions of the word "emeroydez". Maimonides, a famous medieval Jewish physician and scholar, was born in Cordova, Spain in 1135 (or 1138) and was named Moshe Ben Maimon (Maimonides is the Greek version, with the patronimic sufix "ides"). He was the official physician of the Egyptian court, attending the Vizier al-Fadil the Regent of Egypt, while the Sultan, Saladin the Great, was fighting the crusades. Richard the Lionheart reportedly heard of his skills and invited him to be his physician but Maimonides preferred to stay in Egypt. Maimonides wrote a Treatise on Hemorrhoids. ${ }^{13}$ The fact of the matter is that ancient Hebrews interpreted the word as hemorrhoids or tumors notwithstanding, and hemorrhoids or any similar anal pathology were regarded as causes of severe suffering. This fact has not changed to date. It is significant to realize that the Bible, before Christ and after, or Hippocrates and Maimonides for that matter, both of whom were the most distinguished avant-garde physicians of their time, and who clearly and specifically wrote about hemorrhoids and their treatments in their treaties, did indeed refer to the same issue. ${ }^{14}$

The most important point deriving from this historical data presented here is, in our view, that crucial problems to be solved in a hemorrhoid patient still are, as has been for more than 2000 years, bleeding, prolapse, thrombosis, and their complications thereof. Another one is the realization that the more aggressive interventions were usually done to induce scarring, or to remove the hemorrhoids, or to devascularize them, which is what essentially is done today. In this regard, many giant figures in the past such as (in alphabetic order) Aetius of Amida, Albucasis, Ambroise Paré, Avicenna, CeIsus (Aulus Cornelius Celsus), Cornelius, Chassaignac, Galen, Hippocrates, Maimonides, PauI of Aegina, Salmon, Stahl, and several others, applied burning with red iron, surgical knoting, or excisons as treatments. ${ }^{15}$ They did conceptually perform the same procedures as current practice, and did face the same challenges.

This past history notwithstanding, the vascular nature of hemorrhoids as the core issue of this disease was extensively demonstrated by several authors along the 20th century. Defined as a disease of the corpus cavernosi recti, or arteriovenous fistulae, or arteriovenous malformations, or even arteriovenous proliferations consequent to local trauma and inflammation, hemorrhoids were consensually regarded as vascular aberrations of the anal canal by the majority of proctologists. They are small conglomerates of vessels and not merely varicose veins

Conservative treatments were applied throughout History, using ointments (with or without extracts od Acacia leaves, or from cannabis?) by Egyptians and countless physicians including different sorts of creams and baths. Minor interventions included injection of sclerosing agents (sclerotherapy), rubber band ligations (RBL), freezing (cryotherapy or cryosurgery) or heating/coagulation processes such as infrared laser coagulation (IRC) treatments (mostly Nd:YAG neodymium-doped yttrium aluminum garnet - $\mathrm{Nd}: \mathrm{Y}_{3} \mathrm{Al}_{5} \mathrm{O}_{12}$ - lasers) to induce necrosis and scarring (one more modern version of "burning"). Heat applied by bipolar diathermy 
also induces coagulative necrosis, inflammation and scarring/fibrosis, and was shown to be equivalent to or better than IRC in some studies. ${ }^{16} \mathrm{CO}_{2}$ lasers were used mostly as precision knives with the proclaimed benefit of inducing less tissular and sphincter damage thus leading to better recovery from "classic" excisional surgery using scalpels, scissors, or monopolar electrocautery. ${ }^{17}$ Radiofrequency ablation is one of the newest "kids on the block" with interesting initial results and does merit further studies. ${ }^{18}$ Dissection and division devices using bipolar energy such as Ligasure ${ }^{\circledR}$ (Valleylab, Boulder, CO), a bipolar electrothermal energy sealing instrument, or the Harmonic ${ }^{\circledR}$ shears (Ethicon Endosurgery, Cinncinati, $\mathrm{OH}$ ), based on heating from ultrasound waves, have been introduced for excisional hemorrhoidectomy, however no revolutionary effect was observed in most studies to justify their use as routine practice. ${ }^{19,20}$

In the final analysis, hemorrhoids, regardless of their still no unified pathophysiology, remain a medical problem only when symptomatic. These include bleeding, thrombosis, prolapse, and other secondary complications. Their interventional treatments are, excitingly and interestingly enough, variations of the same "burning, knoting, and excising" as performed for over 2000 years.

\section{REFERENCES}

1. Loeder PB, Kamm MA, Nicholls RJ, Phillips RK. Haemorrhoids: pathology, pathophysiology and aetiology. Br J Surg. 1994;81:946-54.

2. Sobrado CW Jr. Doença hemorroidária: ligar, grampear ou cortar? In: castro LP, Savassi-Rocha PR, Lacerda Filho A, Conceição SA, editors. Tópicos em gastroenterologia: avanços em coloproctologia. Ed. Medsi, Rio de Janeiro. 2001. p. 415-45.

3. Adams F. The genuine works of hippocrates, vol. II; 1849. p. 825-30. London.

4. Santos PR. The words "hemorrhoids" in Hebreu literature. Brasil Med. 1939;53:204-8.

5. The Holly Bible. The new King James Version. Nashville: Thomas Nelson Publishers; 1985.

6. First book of Samuel in the Old testament (1 Samuel. 5:9).

7. Goligher JC. Surgery of the anus, rectum and colon. 5th ed. London: Baillière Tindall; 1984, 101, pp. 98.

8. Griffin JP. Plague, rats and Bible again. J R Soc Med. 2006;99:387.

9. Ellesmore S, Windsor ACJ. Surgical history of haemorrhoids. In: Khubchandani I, Paonesa N, Khawaja A, editors. Surgical treatment of hemorrhoids. London Limited: Springer-Verlag; 2009. p. 1.

10. Khan IA. Plague:the dreadful visitation occupying the human mind for centuries. Trans R Soc Trop Med Hyg. 2004;98:270-7.

11. Morgado PJ, Suarez JA, Gómez LG, Morgado P. Histoclinical basis for a new classification of hemorrhoidal disease. Dis Colon Rectum. 1988;31:474-80.

12. Arderne J. In: Power D, editor. Treatises of fistula in ano, hemorrhoids and clysters. London: K. Paul, Trench, and Trubner, and H. Frowde, Oxford University Press; 1910.

13. Magrill D, Sekaran R. Maimonides: an eary but accurate view on the treatment of haemorrhoids. Postgrad Med J. 2007;83:352-4.

14. Laufman H. The history of hemorrhoids. Am J Surg. 1941:38187.

15. Adams F. The seven books of Paulus Aeginata. Book 6. Sec 79; 1844-1847. p. 403-4. London.

16. Lohsiriwat V. Hemorrhoids: from basic pathophysiology to clinical management. World J Gastroenterol. 2012;18:2009-17.

17. Pandini LC, Nahas SC, Nahas CSR, Marques CFS, Sobrado CW, Kiss DR. Surgical treatment of haemorrhoidal disease with $\mathrm{CO}_{2}$ laser and Milligan-Morgan cold scalpel technique. Colorectal Dis. 2006;8:592-5.

18. Gupta PJ. Radiofrequency ablation and plication: a nonresectional therapy for advanced hemorrhoids. J Surg Res. 2005;126:66-72.

19. Milito G, Cadeddu F, Muzi MG, Nigro C, Farinon AM. Haemorrhoidectomy with Ligasure vs conventional excisional techniques: meta-analysis of randomized controlled trials. Colorectal Dis. 2010;12:85-93.

20. Sobrado CW, Mester M, Sobrado L, Louzada ACS. Main disadvantages of hemorrhoidectomy. In: Ratto C, Parello A, Litta F, editors. Hemorrhoids. Coloproctology, vol. 2. Cham: Springer; 2018.,

http://dx.doi.org/10.1007/978-3-319-53357-5_25.

Carlos Walter Sobrado (iD *, Marcelo Mester

Universidade de São Paulo, Faculdade de Medicina, Departament of Gastroenterology, Digestive and Colorectal Surgery Division, São Paulo, SP, Brazil

*Corresponding author. E-mail: cwsobrado@hotmail.com (C.W. Sobrado). 2237-9363/@ 2020 Sociedade Brasileira de Coloproctologia. Published by Elsevier Editora Ltda. This is an open access article under the CC BY-NC-ND license (http:// creativecommons.org/licenses/by-nc-nd/4.0/). https://doi.org/10.1016/j.jcol.2020.05.006 